\title{
Biochemical-genetic approach towards the systematics of lechwe Kobus leche
}

\author{
Daniele DE MENEGHI, Marco APOLLONIO and Günther B. HARTL
}

De Meneghi D., Apollonio M. and Hartl G. B. 1995. Biochemical-genetic approach towards the systematics of lechwe Kobus leche. Acta Theriologica 40: 303-308.

Red lechwe Kobus leche leche Gray, $1850(n=3)$, black lechwe $K$. l. smithermani Lydekker, $1900(n=10)$ and Kafue lechwe $K$. $l$. kafuensis Haltenorth, $1963(n=19)$ from Zambia were examined for genetic variability and differentiation at 30 presumptive structural loci using horizontal starch gel electrophoresis. Values of polymorphism $(P=10.0-16.7 \%)$ and average heterozygosity $(H=6.3-7.9 \%)$ were within the range commonly found in ungulates. Genetic variability was lowest in the red lechwe, which may be due to a genetic bottleneck the Zambia population experienced some 50 years ago. Relative $\left(F_{S T}=21 \%\right.$ ) and absolute (Nei's $\left.1978, D=0.020-0.023\right)$ genetic differentiation were in accordance with the subspecies status proposed for red lechwe, black lechwe, and Kafue lechwe on the basis of morphological characters.

Dipartimento di Patologia Animale e Ecologia, University of Torino, Via Nizza 52, 10126 Torino, Italy (DDM); Dipartimento Scienze del Comportamento Animale e dell'Uomo, University of Pisa, Via Volta 6, 56126 Pisa, Italy (MA); Institut für Haustierkunde der Christian-Albrechts-Universität Kiel, Biologiezentrum, Olshausenstraße 40, D-24118 Kiel, Germany (GBH)

Key words: Kobus leche, Reduncinae, biochemical systematics, genetic variability, electrophoresis, allozymes

\section{Introduction}

Despite a large number of extant taxa, little is known of electrophoretic variability and differentiation in antelopes. A study of the biochemical systematics of representatives of several subfamilies and tribes of antelopes was reported by Georgiadis et al. (1990), and genetic variability and differentiation within the Hippotraginae was evaluated by Grobler and Van der Bank (1993). Electrophoretic variability has been assessed in populations of Speke's gazelle Gazella spekei (Templeton et al. 1987), Arabian oryx Oryx leucoryx (Vassart et al. 1991), the sand gazelle Gazella leptoceros (Granjon et al. 1991), the blesbok Damaliscus dorcas, and the springbok Antidorcas marsupialis (Bigalke et al. 1993). In many taxa subspecies have been described on the basis of superficial morphological differences. Almost no data are available to assess their validity from the perspective of population genetics. 
Lechwe Kobus leche Gray, 1850 are one of the most aquatic antelope species of Africa. They are entirely restricted to seasonally inundated flood plains in the Central Basin of Africa south of the equator, spending much time wading in the water that represents their refugial habitat (Child and von Richter 1969, Williamson 1990). This species has been subdivided into three subspecies, red lechwe K. l. leche Gray, 1850, black lechwe K. l. smithermani Lydekker, 1900, and Kafue lechwe K. l. kafuensis Haltenorth, 1963. A fourth subspecies, Roberts' lechwe K. l. robertsi Rothschild, 1907, is now extinct (Ansell 1960, 1968, Dorst and Dandelot 1970). Black and Kafue lechwe live exclusively in Zambia. Whereas the population of the former increased from 21500 animals in 1975 (Grimsdell and Bell 1975) to 41400 animals in 1983 (Jeffery 1984), that of Kafue lechwe decreased from 94000 animals in 1973 (Bell et al. 1973) to 40000 in 1986 (Spinage 1986). The range of red lechwe is more extensive and includes parts of Angola, Botswana, Namibia, and Zaire. Populations have fluctuated widely, for example in Zambia a decline to no more than 70 individuals in 1948 was followed by an increase to some 3400 animals in 1985 (VVAA 1989).

The three subspecies have been separated mainly on the basis of coat colouration. Red lechwe has a bright chestnut fulvus colouration, only the legs being marked with black. The Kafue lechwe has dark shoulder patches in adult males, and the black lechwe is blackish brown on back and sides. Horns of the Kafue lechwe seem to be slightly thinner than in the other two subspecies (Dorst and Dandelot 1970).

The present study examines taxonomic relationships of lechwe at the biochemical genetic level, and provides a preliminary characterization of genetic variability within the taxa.

\section{Materials and methods}

We obtained samples of skeletal muscle of red lechwe $(n=3$, collection areas Lukanga swamps, Kabwe District in the Central Province), black lechwe ( $n=10$, collection areas Bangweulu swamps, Mpika District in the Northern Province), and Kafue lechwe ( $n=19$, collection areas Lochinvar, Monze District, Blue Lagoon, Mumbwa Distict in Central and Southern Provinces) from Zambia. All animals were shot with rifle from long distance, ie they were not chased, by licensed hunters. Samples were frozen within 4-8 hours after the death of animals at $-18^{\circ} \mathrm{C}$ and shipped frozen to the laboratory. Preparation of tissue extracts, electrophoretic and staining procedures were performed according to routine methods (Hartl and Höger 1986, Grillitsch et al. 1992). The enzyme systems screened, the loci scored, and buffer systems used are given in Table 1. Interpretation of electrophoretic patterns followed Harris and Hopkinson (1976), and Harris (1980). The calculation of indices of genetic variability and differentiation was supported by the BIOSYS programme package (release 1.7) of Swofford and Selander (1989). 
Table 1. Enzyme systems screened and presumptive loci scored in three subspecies of lechwe. Buffer systems: $\mathrm{P}-$ continuous phosphate buffer, $\mathrm{pH}=7.4$; $\mathrm{TC}-$ continuous tris-citrate buffer, $\mathrm{pH}=8.0$ (for details see Grillitsch et al. 1992).

\begin{tabular}{ll}
\hline Enzyme system (abbreviation, E.C. number, buffer system used) & Locus \\
\hline Lactate dehydrogenase (LDH, 1.1.1.27, P) & Ldh-1, -2 \\
Malate dehydrogenase (MDH, 1.1.1.37, TC) & Mdh-1, -2 \\
Malic enzyme (ME, 1.1.1.40, TC) & Me-1,-2 \\
Isocitrate dehydrogenase (IDH, 1.1.1.42, TC) & Idh-1,-2 \\
6-Phosphogluconate dehydrogenase (PGD, 1.1.1.44, P) & Pgd \\
Glyceraldehyde-3-phosphate dehydrogenase (GAPDH, 1.2.1.12, TC) & Gapdh \\
NADH-diaphorase (DIA, 1.6.2.2, TC) & Dia \\
Catalase (CAT, 1.11.1.6, TC) & Cat \\
Superoxide dismutase (SOD, 1.15.1.1, P) & Sod-1,-2 \\
Aspartate aminotransferase (AAT, 2.6.1.1, TC) & Aat-1, -2 \\
Glutamate-pyruvate-transaminase (GPT, 2.6.1.2, TC) & Gpt \\
Pyruvate kinase (PK, 2.7.1.40, TC) & Pk \\
Adenylate kinase (AK, 2.7.4.3, TC) & Ak-1,-2 \\
Phosphoglucomutase (PGM, 2.7.5.1, P) & Pgm-1 \\
Esterases (ES, 3.1.1.1, P) & Es-d, Es-1 \\
Peptidases (PEP, 3.4.11, P) & Pep \\
Aminoacylase-1 (ACY-1, 3.5.1.14, TC) & Acy-1 \\
Adenosine deaminase (ADA, 3.5.4.4, TC) & Ada \\
Aldolase (ALDO, 4.1.2.13, TC) & Aldo \\
Fumarate hydratase (FH, 4.2.1.2, TC) & Fh \\
Mannosephosphate isomerase (MPI, 5.3.1.8, P) & Mpi \\
Glucosephosphate isomerase (GPI, 5.3.1.9, P) & Gpi \\
\hline & \\
\hline
\end{tabular}

\section{Results}

Five out of 30 presumptive structural loci were polymorphic and differentially diagnostic, namely (tetrameric structure of the corresponding allozymes as inferred from heterozygous phenotypes in parentheses): Me-1 (4), Acy-1 (2), Ada (1), Mpi (1), and $G p i(2)$. Allelic frequencies, the proportion of polymorphic loci ( $P$, 99\% criterion), the mean number of alleles per locus (A), expected (Nei's 1978, unbiased $H$ ) and observed $\left(H_{o}\right)$ average heterozygosity, and the inbreeding coefficient $\left(F_{I S}\right)$ are given in Table 2 . In black lechwe, genotype frequencies at Gpi showed a significant deficiency of heterozygotes ( $p=0.003$, exact probability). Of the total gene diversity, $21 \%\left(F_{S T}=0.212\right)$ was due to diversity among populations (subspecies). Nei's (1978) unbiased genetic distances and modified Rogers distances (Wright 1978) are given in Table 3. 
Table 2. Allelic frequencies and indices of genetic variation in three subspecies of lechwe. $p-$ allelic frequency, $h\left(h_{0}\right)$ - expected (observed) single locus heterozygosity (Nei's 1978, unbiased h), $P$ proportion of polymorphic loci, $A$ - mean number of alleles per locus, $H\left(H_{0}\right)$ - expected (observed) average heterozygosity (Nei's 1978, unbiased $H$ ), $F_{I S}$ - inbreeding coefficient. Overall values are calculated over 30 loci.

\begin{tabular}{|c|c|c|c|c|c|c|c|}
\hline \multirow{3}{*}{$\begin{array}{l}\text { Locus } \\
M e-1\end{array}$} & \multirow{3}{*}{$\begin{array}{c}\text { Allele } \\
a\end{array}$} & \multicolumn{2}{|c|}{$\begin{array}{l}\text { Black lechwe } \\
\quad(n=10)\end{array}$} & \multicolumn{2}{|c|}{$\begin{array}{l}\text { Red lechwe } \\
\quad(n=3)\end{array}$} & \multicolumn{2}{|c|}{$\begin{array}{l}\text { Kafue lechwe } \\
\quad(n=19)\end{array}$} \\
\hline & & $p$ & & $p$ & & $p$ & \\
\hline & & 0.700 & $\mathrm{~h}=0.468$ & 1.0 & $\mathrm{~h}=0.0$ & 0.632 & $\mathrm{~h}=0.526$ \\
\hline & $b$ & 0.250 & $\mathrm{~h}_{0}=0.500$ & 0.0 & $\mathrm{~h}_{0}=0.0$ & 0.211 & $\mathrm{~h}_{0}=0.546$ \\
\hline & $c$ & 0.050 & & 0.0 & & 0.157 & \\
\hline \multirow[t]{4}{*}{ Acy-1 } & $a$ & 0.400 & $\mathrm{~h}=0.721$ & 0.500 & $\mathrm{~h}=0.600$ & 0.184 & $\mathrm{~h}=0.605$ \\
\hline & $b$ & 0.100 & $\mathrm{~h}_{0}=0.400$ & 0.0 & $\mathrm{~h}_{0}=0.333$ & 0.0 & $h_{0}=0.737$ \\
\hline & $c$ & 0.150 & & 0.0 & & 0.289 & \\
\hline & $d$ & 0.350 & & 0.500 & & 0.527 & \\
\hline \multirow[t]{2}{*}{$A d a$} & a & 0.850 & $\mathrm{~h}=0.268$ & 0.500 & $\mathrm{~h}=0.600$ & 0.842 & $\mathrm{~h}=0.273$ \\
\hline & b & 0.150 & $\mathrm{~h}_{0}=0.300$ & 0.500 & $\mathrm{~h}_{0}=1.0$ & 0.158 & $\mathrm{~h}_{\mathrm{o}}=0.316$ \\
\hline \multirow[t]{3}{*}{$M p i$} & $a$ & 1.0 & $\mathrm{~h}=0.0$ & 0.167 & $\mathrm{~h}=0.733$ & 0.342 & $\mathrm{~h}=0.462$ \\
\hline & b & 0.0 & $\mathrm{~h}_{0}=0.0$ & 0.500 & $\mathrm{~h}_{0}=0.333$ & 0.658 & $\mathrm{~h}_{\mathrm{o}}=0.474$ \\
\hline & $c$ & 0.0 & & 0.333 & & 0.0 & \\
\hline \multirow[t]{2}{*}{$G p i$} & $a$ & 0.300 & $\mathrm{~h}=0.442$ & 0.0 & $\mathrm{~h}=0.0$ & 0.658 & $\mathrm{~h}=0.462$ \\
\hline & $b$ & 0.700 & $\mathrm{~h}_{0}=0.0$ & 1.0 & $\mathrm{~h}_{0}=0.0$ & 0.342 & $\mathrm{~h}_{0}=0.474$ \\
\hline$P$ & & \multicolumn{2}{|c|}{0.133} & \multicolumn{2}{|c|}{0.100} & \multicolumn{2}{|c|}{0.167} \\
\hline$A$ & & \multicolumn{2}{|c|}{1.23} & \multicolumn{2}{|c|}{1.13} & \multicolumn{2}{|c|}{1.23} \\
\hline$H$ & & \multicolumn{2}{|c|}{0.063} & \multicolumn{2}{|c|}{0.064} & \multicolumn{2}{|c|}{0.079} \\
\hline$H_{o}$ & & \multicolumn{2}{|c|}{0.040} & \multicolumn{2}{|c|}{0.056} & \multicolumn{2}{|c|}{0.084} \\
\hline$F_{I S}$ & & \multicolumn{2}{|c|}{0.365} & \multicolumn{2}{|c|}{0.125} & \multicolumn{2}{|c|}{-0.063} \\
\hline
\end{tabular}

Table 3. Genetic distances among three subspecies of lechwe. Above diagonal: modified Rogers distances (Wright 1978), below diagonal: Nei's (1978) unbiased genetic distances.

\begin{tabular}{lccc}
\hline & Black lechwe & Red lechwe & Kafue lechwe \\
\hline Black lechwe & - & 0.168 & 0.144 \\
Red lechwe & 0.023 & - & 0.166 \\
Kafue lechwe & 0.020 & 0.023 & - \\
\hline
\end{tabular}

\section{Discussion}

Both average heterozygosity and the proportion of loci polymorphic in the three subspecies of lechwe are within the range commonly found in ungulates (see Hartl and Pucek 1994, for review). The lower $P$ - and $A$-values in the red lechwe may be 
due to a bottleneck the population in Zambia experienced some decades ago (see Introduction), which is supported by high frequencies of variant alleles at the polymorphic loci. It is typical for genetic bottlenecks that most of the rare alleles are lost whereas the frequencies of some of them may be dramatically raised (cf Nei et al. 1975). Since values of average heterozygosity are similar when constituted either by a few highly polymorphic or many slightly polymorphic loci (Table 2), $H$ alone is not a very powerful indicator of genetic depletion (see Hartl and Pucek 1994, for further discussion). However, due to small sample size in the red lechwe, the lower $P$ - and $A$-values need to be proven by further investigation. In the black lechwe, the lack of heterozygotes at the Gpi locus and the highly positive $F_{I S}$-value suggest some subdivision within the Zambian population of this subspecies. Alternatively, these results may be explained by introgression of the Kafue lechwe alleles into populations of the black lechwe. Unfortunately, biological information on lechwe populations in Zambia is inadequate to support or refute these hypotheses.

Red, black and Kafue lechwe proved to be closely related, showing a genetic distance and an $F_{S T}$-value of a magnitude comparable to that found among subspecies in other ungulate taxa. For example, Gyllensten et al. (1983) reported Nei distances up to 0.025 and a $G_{S T}\left(F_{S T}\right)$ of about $22 \%$ among subspecies of European red deer Cervus elaphus. The results of the present study are in accordance with the fact that morphological differences among the three lechwe subspecies are slight and involve little but variation in patterns of coat colour.

Acknowledgements: We would like to thank E. and F. Vidale, professional hunters in Lusaka (Zambia), for providing facilities and help in collecting samples. The excellent technical assistance of A. Haiden is gratefully acknowledged.

\section{References}

Ansell W. F. H. 1960. Mammals of Northern Rhodesia. Government Printer, Lusaka: 1-187.

Ansell W. F. H. 1968. The black lechwe antelope. Black Lechwe 1: 13-15.

Bell R. H. V., Grimsdell J., Jr, Van Lavieren L. P. and Sayer J. A. 1973. Census of Kafue lechwe by aerial stratified sampling. East African Wildlife Journal 11: 55-74.

Bigalke R. C., Hartl G. B., Berry M. P. S. and Van Hensbergen H. J. 1993. Population genetics of the springbok Antidorcas marsupialis - a preliminary study. [In: Ecological genetics in mammals. G.

B. Hartl and J. Markowski, eds]. Acta Theriologica 38, Suppl. 2: 103-111.

Child G. and von Richter W. 1969. Observations on ecology and behaviour of lechwe, puku and waterbuck along the Chobi river, Botswana. Zeitschrift für Säugetierkunde 34: 275-295.

Dorst J. and Dandelot P. 1970. A field guide to the larger mammals of Africa. Collins, London: 1-287.

Georgiadis N. J., Kat P. W., Oketch H. and Patton J. 1990. Allozyme divergence within the Bovidae. Evolution 44: 2135-2149.

Granjon L., Vassart M., Greth A. and Cribiu E.-P. 1991. Genetic study of Sand gazelles (Gazella subgutturosa marica) from Saudi Arabia. Zeitschrift für Säugetierkunde 56: 169-176.

Grillitsch M, Hartl G. B., Suchentrunk F. and Willing R. 1992. Allozyme evolution and the molecular clock in the Lagomorpha. Acta Theriologica 37: 1-13.

Grimsdell J. J. R. and Bell R. H. B. 1975. Ecology of the black lechwe in the Bangweulu basin of Zambia. Animal Productivity Research Report Ar 1. Falcon Press Ltd., Ndola: 1-175. 
Grobler J. P. and Van der Bank F. H. 1993. Genetic diversity and differentiation of the three extant southern African species of the subfamily Hippotraginae (Family: Bovidae). Biochemical Systematic and Ecology 21: 591-596.

Gyllensten U., Ryman N., Reuterwall C. and Dratch P. 1983. Genetic differentiation in four European subspecies of red deer (Cervus elaphus L.). Heredity 51: 561-580.

Harris H. 1980. The principles of human biochemical genetics. Elsevier-North Holland, Amsterdam: $1-554$.

Harris H. and Hopkinson D. A. 1976. Handbook of enzyme electrophoresis in human genetics. Elsevier-North Holland, Amsterdam (unnumbered pages).

Hartl G. B. and Höger H. 1986. Biochemical variation in purebred and crossbred strains of domestic rabbits (Oryctolagus cuniculus L.). Genetic Research, Cambridge 48: 27-34.

Hartl G. B. and Pucek Z. 1994. Genetic depletion in the European bison (Bison bonasus) and the significance of electrophoretic heterozygosity for conservation. Conservation Biology 8: 167-174.

Jeffery R. 1984. Black lechwe census, October, 1983. Black Lechwe 6: 23.

Nei M. 1978. Estimation of average heterozygosity and genetic distance from a small number of individuals. Genetics 89: 583-590.

Nei M., Maruyama T. and Chakraborty R. 1975. The bottleneck effect and genetic variability in populations. Evolution 29: 1-10.

Spinage C. A. 1986. The natural history of antelopes. Croom Helm, London: 1-203.

Swofford D. L. and Selander R. B. 1989. BIOSYS-1. A computer program for the analysis of allelic variation in population genetics and biochemical systematics. Release 1.7. Center for Biodiversity, Illinois Natural History Survey, 607 E. Peabody Dr., Champaign, Illinois 61820, USA.

Templeton A. R., Davis S. K. and Read B. 1987. Genetic variability in a captive herd of Speke's gazelle (Gazella spekei). Zoo Biology 6: 305-313.

VVAA 1989. Endangered animal life of the world Vol. 2. Curcio, Rome: 1-70. [In Italian]

Vassart M., Granjon L. and Greth A. 1991. Genetic variability in the Arabian Oryx (Oryx leucoryx). Zoo Biology 10: 399-408.

Williamson D. T. 1990. Habitat selection by red lechwe (Kobus leche leche Gray, 1850). African Journal of Ecology 28: 89-101.

Wright S. 1978. Evolution and the genetics of populations. Vol. 4. Variability within and among natural populations. University of Chicago Press, Chicago: 1-580.

Received 14 November 1994, accepted 16 August 1995. 